\title{
Science, Technology, and Innovation Governance for Social Inclusion and Sustainable Development in Latin America
}

\author{
Luis Antonio Orozco, Gonzalo Ordóñez-Matamoros, \\ Javier Garcia-Estévez, Jaime Humberto Sierra-González, \\ and Isabel Bortagaray
}

\subsection{INTRODUCTION}

Latin America and the Caribbean (LAC) is a plural and diverse region endowed with wide munificence of natural resources, peoples, and

\footnotetext{
L. A. Orozco $(\bowtie)$

School of Management, Universidad Externado de Colombia, Bogotá, Colombia

e-mail: luis.orozco@uexternado.edu.co

G. Ordóñez-Matamoros

Universidad Externado de Colombia, University of Twente, Bogotá, Colombia e-mail: gonzalo.ordonez@uexternado.edu.co
}

(C) The Author(s), under exclusive license to Springer Nature Switzerland AG 2021

L. A. Orozco et al. (eds.), Science, Technology, and Higher Education, Palgrave Studies in Democracy, Innovation, and Entrepreneurship for Growth, https://doi.org/10.1007/978-3-030-80720-7_1 
culture. This involves high heterogeneity across countries and several differences in terms of policy orientations, the capacity to create economic growth, and the way to meet social and environmental needs. The region has been improving in terms of GDP growth since 2016 but without substantially improving the existing income gap, poverty rate, and Gini coefficient (ECLAC et al., 2019).

Latin America is one of the most unequal regions in the world, as ascertained by several indicators concerning education, health, and social security services, as well as income and wealth distribution (ECLAC, 2019). The Inter-American Development Bank Research Network project on social exclusion in Latin American and the Caribbean has long stated that inequalities are associated with the absence of opportunities (Behrman et al., 2002).

Several initiatives like those led by the Economic Commission for Latin America and the Caribbean (ECLAC) regard projects intended to defeat poverty and enhance social inclusion (Cepal, 2006) in an effort to boost the region into the route to Agenda 2030 for sustainable development (Sustainable Development Goals-SDGs ${ }^{1}$ ). Such initiatives have promoted the enactment of better policies for social development through inclusive economic growth that includes social protection and the creation of work opportunities with dignifying jobs (Cepal, 2016). Likewise, the OECD LAC Regional Program (LACRP) has tried to enhance social inclusion through efforts to strengthen institutions, improve governance, and increase productivity (OCDE, 2017).

\footnotetext{
J. García-Estévez

Universidad de Los Andes, Bogotá, Colombia

e-mail: jh.garcia@uniandes.edu.co

J. H. Sierra-González

Pontificia Universidad Javeriana, Bogotá, Colombia

e-mail: jhsierra@javeriana.edu.co

I. Bortagaray

Universidad de La República, Montevideo, Uruguay

${ }^{1}$ See SDG \#10 goal 10.2 that stated "by 2030 empower and promote the social, economic and political inclusion of all irrespective of age, sex, disability, race, ethnicity, origin, religion or economic or other status".
} 
The concept of governance began to be used in the neoliberal rationale to refer to the bargaining process and agreements between public and private organizations in the realm of issues that governments cannot face alone (Bevir, 2008). The concept appeared in New Institutional Economics' frame to mean the agreements that infuse order, mitigate the conflict, and realize mutual gains in the contractual or hybrid forms between markets and hierarchies (Williamson, 1996, 2005). Rhodes (1996, p. 652) extends this vision claiming that "governance refers to 'self-organizing interorganizational networks' (that) complement markets and hierarchies as governing structures for authoritatively allocating resources and exercising control and coordination".

Governance includes not only a bargaining process and agreements between public and private actors, but also civil society and different regions and jurisdictions as happening in the European Union. In the realm of multilateral agencies like the United Nations, the World Bank, or the OCDE emerged the idea of global governance, promoting the coordination of policies among countries to pursue common goals like social and environmental development and sustainability. Then, awareness about poverty eradication for improving social inclusion and justice has been embedded in the concept of governance or good governance (Bevir, 2008).

Governance for social inclusion means that public policy does not exclusively belong to the State. Instead, several if not all actors belonging to civil society can participate in the definition of problems and the ways to solve them. Thus, governance implies hybrid structures that organize multiple stakeholders' participation in a multi-jurisdictional and multiregional scenario in which formal and informal spaces and mechanisms of relationships and accountability can be performed (Bevir, 2008).

The idea of governance was introduced in Latin America by multilateral agencies like The World Bank, The United Nations Development Programme (UNDP), and the Inter-American Development Bank based on their interest to improve the management of international aid and funding across the region (Zurbriggen, 2011). The aid programs that want to alleviate poverty have been one of the most important efforts to introduce governance as a means to coordinate public, private, and civil organizations for social inclusion.

Here it is valuable to remember the ideas of Zygmunt Bauman about the social exclusion. He stated that "Uncertainty, insecurity's principal cause, is by far the most decisive tool of power-indeed, its very 
substance" (Bauman, 2011, p. 42). In fact "Human vulnerability and uncertainty is the foundation of all political power" (Bauman, 2011, p. 122). Then, the manipulation of uncertainty is an instrument for discrimination between us and them. Bauman understands that "The fear which democracy and its offspring, the social state, promised to uproot has returned with a vengeance. Most of us, from the bottom to the top, nowadays fear the threat, however unspecified and vague, of being excluded, proved inadequate to the challenge, snubbed, refused dignity and humiliated... On the diffuse and misty fears that saturate presentday society, politicians as much as the consumer markets are eager to capitalize". And continues "The risks to which democracies are currently exposed are only partly due to the way state governments desperately seek to legitimize their right to rule and to demand discipline by flexing their muscles and showing their determination to stand firm in the face of the endless, genuine or putative, threats to human bodies - instead of (as they did before) protecting their citizens' social usefulness, respected places in society, and insurance against exclusion, the denial of dignity and humiliation". (Bauman, 2011, pp. 18-20). Finally, he proposed the alternative in terms of provision of security and safety using fear as a channel to engage voters and costumers. He saw "That alternative seems to have been recently located (...) in the issue of personal safety: current or portending, overt or hidden, genuine or putative fears of the threats to human bodies, possessions and habitats-whether arising from pandemics and unhealthy diets or lifestyle regimes, or from criminal activities, antisocial conduct by the 'underclass', or most recently global terrorism" (Bauman, 2011, p. 54).

In LAC countries, several initiatives began to provide support to vulnerable families to alleviate poverty and exclusion. The management of fears and uncertainty with the discourse of governance as a tool to promote democracy with social inclusion began to monger the policy and its social programs. However, the creation of collateral damages, as Bauman (2011) conceptualized the unintended consequences of policies, emerged in the region. As Zurbriggen (2011) pointed out, programs such as Familias por la Inclusión Social in Argentina; Puente-Chile Solidario; Bolsa Familia in Brazil; Panes in Uruguay; Red de Protección Social in Nicaragua; Familias en Acción in Colombia; Programa de Asignación Familiar in Honduras, and Bono Solidario in Ecuador do not contribute to improve governance and democracy with the empowerment of citizenship and social capital. These programs just created a market for 
Non-Governmental Organizations (NGOs) to deliver social assistance and allowed private organizations to become providers of social services such as health care and food supply.

With the governance discourse, the first case of privatization in Latin America was the infrastructure development and public services as water and sanitary issues. The State was in charge of coordinating several actors' efforts to warranty the quality and efficiency in social services provided by privates and controlled by civil organizations. In Colombia, a group of contractors began to centralize the water services due to their capacity to sell the idea that they will be able to provide a more efficient administration. However, the entrepreneurs began to be corrupt and civil society and unions were not taken into account. The losses for mismanagement created more and more profound problems, showing that private interest could lead to more trouble for social and economic development (Ardila, 2013; Colmenares, 2013), damaging not only public services, also, in this case, the financial markets (Orozco et al., 2018). In Argentina, private multinational corporations faced several shortcomings in terms of the lack of previous studies, badly designed biddings, and deficient contracts in an inadequate regulatory framework that finalized in international judiciary tribunals and expensive lawsuits. In Honduras and Peru there is not an organized market, the tanks cars abuse with their power, the quality of the liquid is not trustworthy and the water became an expensive good (Zurbriggen, 2011). The decentralization also carried out more challenges in terms of controls and disputes for the access and management of resources, widening the gap in the concentration of wealth.

The STI policies in LAC have disjunctives between social and environmental needs and economic growth with scarce resources for creating opportunities with science, technology, and innovation (STI). It is not easy for policymakers to go beyond statistics and create with the available information new meanings to foster the decision-making that encompasses the restrictions and limitations in productivity and industrial evolution with the problems around poverty and environmental degradation. With scare resources, dilemmas like investing in STI for the oil industry that assure several jobs instead to recover a river damaged by oil extraction, a river that in the long term assure survival, surround the policymakers that need more insight to understand ways to improve governance and straight institutions to assure social justice, environmental protection, reduce corruption and create opportunities for enhancing the quality of life. 
The ideology that STI is a tool to achieve competitiveness for the nations created more damages than benefits. As the Nobel Price Paul Krugman noted many years ago, "competitiveness is a meaningless word when applied to national economies. And the obsession with competitiveness is both wrong and dangerous" (Krugman, 1994, p. 44). The ideology was developed mainly by Michael Porter in which the US's neoliberal interest spread a model that nations must be managed as a private corporation instead of creating conditions for welfare (Aktouf, 2008). Aktouf et al., (2005, p. 184) stated that "For Habermas, the morality of a given utterance depends on the dialogical exchange made up of a claim to validity by a speaker, objections to this claim by other speakers, and arguments by the speaker in response to these objections, all of which occurs within the framework of a space of free speech. The problem here is that Porter's positivism imposes the number and nature of competitive forces and the result of the ensuing analysis of industries as scientific and therefore non-debatable truths. It is in this sense that Porter's model is a formidable instrument of domination". Then, Aktouf (2008, p. 170) questioned "¿Se puede impunemente transformar de esta manera a los Estados en comités de gestión de los intereses financieros transnacionales, y a las naciones en espacios dedicados unicamente a la competencia entre gigantes empresariales obstinados en acaparar el único resultado presentado como deseable en todo lo que hacen: la multiplicación más rápida posible del dinero por el dinero mismo?" Porter's framework cannot explain the reality of market dynamics and, instead, provided simplistic toolkits for managers - diamonds, forces, and chainsto promote the creation of profits in a struggle between firms and countries in wild capitalism (Aktouf, 2004). ${ }^{2}$ Aktouf (2008, p. 177) concludes that "Al convertir al planeta en un gran campo de batalla para la competitividad infinita, bajo el sólo apremio de la maximización de los beneficios y los dividendos, Porter nos conduce tan simplemente a hacer depender lo macroeconómico de lo microeconómico y las politicas nacionales

2 "The determinants in the diamond model are a necessary reduction to enable the continuity of Porter's reasoning, in that he attempts to compare different economies without having to concern himself with their differences. It is not easy to compare the maximalist financial logic of the self-regulated, American-styled capitalist market (which in recent times has moved towards unimaginable and irrational summits of speculation since the heady rush engendered and maintained by Internet businesses and the Enron and Worldcom scandals) to the kinds of 'stale-regulated, social-market' industrial capitalism found in Germany and Japan" (Aktouf, 2004, p. 28). 
de las decisiones del mundo de los negocios. El tratamiento de la economía sólo se concibe en un muy corto plazo, agravando exponencialmente los desequilibrios, ya desastrosos, entre el Norte y el Sur, y entre los factores de producción mismos (capital, trabajo y naturaleza)".

The movement of competitiveness and public policies' orientation includes STI as a key tool to achieve better indicators in terms of market shares and corporative profits, instead of addressing social and environmental challenges such as poverty, social inclusion, and climate change. The movement of automation and the application of management science and operation research in the name of the advancement of science has been helping entrepreneurs to cut costs in re-engineering process and low wages (as the gospel of Porter instigates), firing people in downsized hierarchies and replaced humans with machines and algorithms. The damage created with the promotion of this ideology sells more than others the belief that competitiveness through STI is the main goal for countries, and the wealth created is distributed around the nation (Gough, 1996). However, the analysis of the crisis of capitalism reveals that the concentration of wealth has been increasing with income inequality (Goda et al., 2017). As Dutrénit and Sutz (2014) show, there is no linear correlation between innovation and international competitiveness, growth, and equal income distribution. The governance of STI between public policy and private corporations with the proposal to make profits and pay more taxes did not improve human development. We agree with the distinguished professor Deirdre McCloskey that "Competitiveness is not a word that a serious economist ever uses" (McCloskey, 2019, p. 2) and the fact that the Sustainable Development Goals (SDGs) does not include the term competitiveness in their discourse. ${ }^{3}$

The United Nations stated that "social inclusion is defined as the process of improving the terms of participation in society, particularly for people who are disadvantaged, through enhancing opportunities, access to resources, voice and respect for rights" (UN, 2016, p. 17). There are several issues in the field of STI to discuss to better understand the process of social inclusion due to the advancement of scientific knowledge. Knorringa et al. (2016) present the debate around frugal innovation. This concept emerged to refer to the new product and services created to solve problems or attending needs for a lot of poor people at the bottom of the

\footnotetext{
3 https://www.undp.org/content/undp/en/home/sustainable-development-goals/bac kground/.
} 
pyramid, creating a "win-win" business in which companies contribute to poverty alleviation at the same time that creates profits, instead of that "frugal innovation will merely exacerbate capitalist exploitation and inequality" (Knorringa et al., 2016, p. 143). Kuhlmann and OrdonezMatamoros (2017) edited a Handbook that addressed a well-known critique of the questionable links between economic growth and social welfare. This might be well known and discussed by this research community but much less popular to a significant part of the science and policy community, especially those involved in developing and governing emerging technologies. For example, do social inclusion results from the transfer of new technologies that communities cannot control? Developing the concept of social value as a result of the creation and use knowledge to develop communities with their own capacities to solve their problems and improve their possibilities to enjoy welfare with dignity, Orozco and Chavarro (2011) showed that solutions imposed in a top-down scheme by the government failed in the case of Chagas disease in Colombia. The scientific solutions supported in the co-design with the community using a bottom-up schema emerged and showed how shared governance of STI could promote welfare and social inclusion. Another example shows how the integration of techno-economic networks in which government, researchers from public and private institutions, not-for-profit organizations, and local communities translate the advancements in biotechnologies to improvements in productivity, increasing the social inclusion for peasant families to the potatoes corps in Colombia (Orozco et al., 2007). Analyzing national innovation systems and social inclusion, Dutrénit and Sutz (2014) evidenced that clear incentive is needed to introduce social inclusion research in research centres and universities and concludes that greater involvement of the innovation beneficiaries is crucial to the success of any social policy. Then the research founded that a multidisciplinary and beneficiary participatory approach to design effective inclusive innovation policies is needed to improve results. In this way, Bortagaray and Gras (2014) show the cases from Bolivia, Colombia, Ecuador, and Peru in the light of the general discussion of STI for inclusive development. The chapter highlights how traditional knowledge and know-how toward searching for solutions for national and local problems are at the center of the discussion. These shifts in STI policy frameworks are still in the planning phases, but deliberation and participation seem crucial for building capabilities and expanding the choices about STI policies for development goals. 
Another example is provided by the different points of view for policies that promote social inclusion. For example, formalizing employment for public agencies means the dignification of work and access to social security and statal support and protection. For informal vendors, it means the loss of dignity due to new conditions of schedules, accountabilities, and less freedom to perform work by their own will. Another issue in STI is the differentiation between users and beneficiaries of scientific and technological advancements. Researchers in molecular biology and biotechnologies could develop new techniques to produce milk with more nutritional compounds. The users are the enterprises in the business of breeding and growing cows, and the beneficiaries could be the children who receive, probably in public dietary programs, the new milk.

The governance and management of STI (GMSTI) and their role in explaining both economic development and social transformation is a growing topic of interest in the international literature, attracting academic, policy, and practitioners' attention alike. In this field, questions increasingly arise regarding GMSTI main features, challenges, and positive and negative effects in Latin America as a developing region that has some valuable lessons to offer. We claim that Latin American scholarly work on the topic has been dramatically underexploited, while its relevance is acknowledged for a better understanding of GMSTI challenges and opportunities in the global north.

Efforts in the investment and promotion of STI, which can create opportunities to overcome social exclusion and advance in sustainability, are modest in Latin American countries. According to the RICyT (2019), the investment in STI, which means just $3 \%$ of the world, reach $0,64 \%$ of the GDP in 2017 and is characterized by the high concentration. Brazil, Argentina, and Mexico represent $86 \%$ of LAC investment. In terms of human capacity, the LAC countries present 1,73 researchers for every one thousand economically active populations, while countries like Spain are near 10 (RICyT, 2019). In terms of education, only 1\% of students belonging to LAC countries presents results at the highest levels of proficiency in mathematics, according to the Program for International Student Assessment (PISA) (ECLAC et al., 2019). Between 2009 and 2015, the mean PISA score in science performance increased from 406 to 412 , almost 100 points below OCDE countries. In general, the enrolment in STI is low, and it is clear the mismatch between the professional skills with the technical requirements that have been reframing in the 
context of the fourth industrial revolution (Ordoñez-Matamoros et al., 2021).

The governance between policy networks defined by law that steer guidelines to create cross-agency collaboration between several actorsgovernment, scientists, universities, firms, able to invest and perform $\mathrm{R} \& \mathrm{D}$, and the evaluation and accountability in online social networks has been one of the key advancements in understanding national innovation systems (Orozco et al., 2019). The main question is how STI governance has been developed to include sustainability with social inclusion regarding the silenced voice of those that contribute to STI governance. Governance as a means of shared administration in which the State must assure the stability of justice and force, and private organizations must attend the rest of the affairs like social services (health, education among others) using the market mechanisms, respond to the neoliberal interest of making more efficient public policy in the division of tasks in which law enforcement and incentives prevent and punish corruption and promote transparency and democracy. However, this top-down approach can be discussed with several cases in the field of STI studies. The way to overcome the social exclusion, understood as a collateral damage that takes advantage of the fears and risks, as Bauman (2011) pointed out, is to develop governance mechanisms in which STI lead to opportunities that dignify the work with the creation of social value that empowers the community to solve their own problems and attend their needs (Orozco \& Chavarro, 2011).

One of the most valuable contributions to advance in critical thinking to imagine and create new governance models is with cases, explanations, and theoretical insights that allow studying the efforts to steer governance toward social inclusion and sustainability. Policymakers and practitioners, in general, need to learn from more cases and experiences to figure out how to rethink their own systems. Thus, this book is a tool to find theoretical approaches and empirical analyses that shed light on broad and specific features in several topics such as sustainability, higher education policy, and institutional models, and funding experiences and challenges, among others. Furthermore, scholars will find some novel methodological approaches and theoretical debates that help improve future research while learning from experiences in the Latin American context. Scholars can also find academic material to support their teaching activities, using cases to enrich their approaches on GMSTI. 
This work is a product of the Network on Governance and Management of Science, Technology, and Innovation-(Red GCTI) from a congress "Governance of science, technology and innovation for inclusive and sustainable development in Latin America" organized in 2019 by Universidad Externado de Colombia, Universidad de los Andes, Pontificia Universidad Javeriana, and the Colombian Association for Scientific Advancement (ACAC), with the support of Colombian Observatory of Science and Technology (OCyT), ACUA Foundation and Fondo Internacional de Desarrollo Agrícola (FIDA).

In October 2014 professors Gonzalo Ordoñez-Matamoros and Luis Antonio Orozco understood that there was a time to give a name of an informal research team that has worked 12 years ago, led by one of the most influential scientists in Colombia, José Luis Villaveces, in the topics of STI in policy, sociology, management, and scientometrics. They organized using the name of Thinking Center for STI Governance, with the PhD program's support in public policy from the Universidad Externado de Colombia, the forum: Science, technology, and innovation as a tool for development. The main idea was to enhance the relationships between Universidad Externado de Colombia and the University of Twente. With the visit of Stefan Kuhlmann, president at that time of EU-SPRI Forum, the idea was to invite the people, not only researchers, interested in STI governance to promote the creation of a community for sharing knowledge, experiences, ideas, and alliances to work together. Also, the idea was to create a space like EU-SPRI in Latin America. The suggestion of an open network began to operate with the support of Diego Andrés Chavarro and María Alejandra Tejada that steered a space for PhD students to show their results in the field of STI. Between January and March 2015 began the discussion about PhD research. The first presentation was Diego Chavarro thesis at SPRU-Sussex University in UK; followed by María Alejandra Tejada and Ernesto Andrade from Twente University in The Netherlands. In April 2015 María Piedad Villaveces contributed to open a space to invite people to plan the Network's activities. Then, several scholars such as Astrid Jaimes, Mónica Salazar, Alejandro Balanzó, Iván Montenegro, Galo Tovar, and Jaime Sierra, among others, began to interact with the idea to perform several activities to promote the research and public discussion of governance and management of STI.

After five years with the interaction of more than 100 persons, in summer 2019 the Red GCTI, integrated by members from academia, 
government, and Civil Society Organizations in Colombia, organized the first conference on this subject in Latin America. More than 700 persons were inscribed for the conference, with 282 attendants. Near 90 papers were submitted from more than 15 countries, including Argentina, Chile, Uruguay, Mexico, Peru, Ecuador, Costa Rica, Panama, Spain, Canada, United Kingdom, United States, Switzerland, and The Netherlands. We selected 20 works that offer an original reflection and results, highlighting in one way or another current trend, challenges and opportunities characterizing STI governance in terms of social inclusion and sustainable development in Latin America.

This effort is organized in two books according to the orientation of the chapters. In this compilation, several researchers bring an academic perspective of institutional arrangements and goal definitions around sustainable development in the context of Latin American countries and the challenges of developing absorptive STI capacities for social inclusion. Chapters tackle the important role of citizen science, science diplomacy, peace building, mission-oriented policies, public innovation, institutional entrepreneurs, and policy networks. In the second volume "Policy and Governance of Science, Technology, and Innovation Social Inclusion and Sustainable Development in Latin América", the chapters show specific features of innovation policies in the framework of Latin American contexts, analyzing the barriers and opportunities for STI governance in the region. In so doing, the books cover both novel and studied topics, but from renewed perspectives that address issues related with the role of institutions, innovation funding, technological trajectories, regional innovation policies, innovation ecosystems, universities, knowledge appropriation, and markets with insights that deal with a new STI framework called the Transformative Innovation Policy, which are approached from both a top-down and bottom-up perspectives.

Thus, the chapters that make up this volume offer a varied and conceptually rich landscape in which cases, contexts, actors, and relationships are used to broaden and deepen relevant discussions. The chapters incorporate new elements and views to renew traditional stances, offer fertile insights about relevant realities, and propose new research and action avenues to face the challenges that Latin American communities confront daily.

The chapters cover two main topics. The first part shows cases that illustrated the STI governance in diplomacy, ecosystems conservation, peace, agricultural production, and sharing economy in which civil society 
and triple-helix interactions are the main issues analyzed in the section. The second part focuses on higher education institutions as the main actor in STI governance for social inclusion. Some works advance in methodological proposals as well as cases in which the STI governance is shown in the frame of transformative innovation and their contribution to peace and social inclusion.

In chapter two Bonilla and Serafim's “Relevance of Science, Technology and Innovation Diplomacy for STI Capacity Building in Central America: the cases of Guatemala, El Salvador and Honduras" text illustrates how latecomers to science, technology, and innovation diplomacy (STID) discussions and analyses in peripheral regions, such as Central America, are, however, taking important steps to build STI capacities for inclusive development. This also provides evidence on the relevance of STID to strengthen capacity building in such a particular context and draws some relevant policy implications for the roads that lay ahead.

In the next chapter, Galvis and Galvis discuss how an effective governance model to protect coral reefs in Colombia was developed bottom-up during the past decade, thanks to the joint efforts and trust of government, civil society, and communities. In fact, "Transdisciplinary Citizen Science connect Caribbean Hope Spots of Colombia to improve Coral Reefs Governance" showcases a citizen's science program associated with scuba diving operators, fishermen, and other volunteer observers, which helped gather massive data based on geo-referenced reports of observations and semi-structured interviews with videos and photos. As a direct outcome of such coordinated effort, the target geographical regions boast substantially higher healthy coral cover and more frequent sightings of vulnerable species listed on the IUCN Red List, higher fishermen's community stewardship, more effective bottom-up schemes of protection, and less visitors in contrast with the Park. This talks loudly about the positive scheme results and the ensuing need to connect case studies within effective protection frameworks to increase governance that guarantees ecological connectivity.

Reina's chapter forwards a conceptual proposal related to CommunityBased Innovation Ecosystems, which he deems an appropriate framework to study processes of communal and transformative innovation in territories affected by heavy social conflict. Thus, "Community-Based Innovation Ecosystems in Peace-building and Resilience Contexts" challenges the notion of innovation "as a transactional process to open new markets in capitalism" and pivots around a socio-technical process of collective 
transformation linked to actions carried out by grassroots organizations and communities. This proposal is embodied by the case study of a community located in a South-Western region (Guapi, Cauca) where diverse social actors, that have been usually excluded, build collaborative interactions in post-conflict/post-agreement contexts.

Likewise, Rojas analyzes the main challenges faced by a developing country such as Colombia in an attempt to organically link local economic development strategies to the manifold opportunities arising from a richly endowed bioeconomy expressed in several regions within the same country. Thus, "Local economic development and the Colombian strategy for a sustainable and inclusive bioeconomy" explores the traits of triplehelix actors related to the progress of development supported by a bioeconomy-based strategy and offers a stance based on local territories and bottom-up participation.

The chapter by Sanabria and Orozco, "Sharing economies and digital platforms: Between access and social inclusion in Colombia", analyzes several cases, performed in collaboration with Connecting the Dots and Sharecollab, the dilemma of platforms that could generate social inclusion and may help disrupt traditional non-inclusive dynamics for market mechanisms, or creating new forms of mega-corporations that exert power and dominance with the new digital technologies in a new wave of capitalism. The cases help to understand the technology as a mediated agent in the frame of Actor Network Theory, to be analyzed by its capacity to traduce the new business models into practices for social inclusion or marginalization. This research extends a previous analysis of the transformation of capitalism with the discourse of sharing economy (Sanabria \& Orozco, 2021).

In the second part of the book, chapter six presents universities as key actors in Chalela, Boni, and Velasco's "Developing transformative innovation through policy experimentation in two Colombian Universities", in which two experiences are examined under the light of transformative innovation. The cases of two regional, privately owned universities are brought forward to illustrate "inclusive and participatory processes that have taken into account voices that are usually excluded in the formulation of university policies". Although the two processes examined are still unfinished, the authors trust that such an approach can offer useful alternatives to improve university governance.

Along the same line, in "The STI contribution of higher education institutions of Cauca to peace building and social inclusion", Castillo and 
co-authors analyze the implementation of territorial peace conceived as the return of the State to territories (e.g., Cauca state) where governmental institutional presence is neglected. The study uses quantitative and qualitative analysis to establish how, despite understandable shortcomings, Caucan universities do develop joint STI initiatives that foster social inclusion with/of social organizations through knowledge diffusion to counter specific problems (e.g., digital divide) and by supporting the design, implementation, and assessment of public policies aimed at boosting human talent in the region.

The next two chapters cover the advancements in methodological issues. "A classification model to analyze inclusion in higher education systems: an approximation from contingency theory" by Ruiz and co-authors examines Colombia's national science, technology, and innovation system plans to include more students in the higher education system as a condition to create the human capital needed to boost socio-economic development. Their concern regards a supply-demand imbalance that creates a governance problem by pressing the inclusion of human capital in higher education organizations, which adds to regional inequalities. Ruiz et al. propose a model to study such a problem and present results showing that shifts in inclusion depend on the development level of regions.

Another case scenario is presented by Cancino et al. in "Methodology for the governance and management of the university as a complex adaptive system based on the three missions: research, education and connecting with its surroundings". The authors propose to examine the sustainability and governance of university-based capacities by redefining the very notion of science, technology, and innovation capabilities in terms of the heterogeneity that characterizes the different types of universities' scientific and technological activities. That is achieved by examining the case of a highstanding public university in Colombia and putting forward a proposal to strengthen the governance and management of its mission.

In the last chapter, Sierra and Ramos' "Science, Technology, Innovation and inclusive development: A country comparison between Colombia and Mexico" discusses the key historical elements that have produced the current situation in both nations and the, consequently, long way to go to for the two countries to build strong knowledge-based economies where opportunities and performance help drive a change in equality and wealth concentration into greater and better distributed resources, opportunities, and social welfare in general. Universities and 
their relationships are showed as an important factor in both cases, giving a framework to understand the governance for STI in the inclusive development.

The books convey original reflections from the science, technology, and innovation policy and governance studies and those related to the development studies field with an approach to social inclusion and sustainability. Social inclusion and sustainable development supported by STI governance have been an essential topic in Latin America, though understudied so far. Then, more than an academic discussion about the conception of governance, in Latin America, the term tends to be more a fashion than a scientific construction using evidence about the changes in the way to understand the relationships between several actors to define and control policies. The books produced by the Red GCTI are an effort to contribute to the academic and practical vision about STI governance.

\section{REFERENCES}

Aktouf, O. (2004). The false expectations of Michael Porter's strategic management framework. Revista Universidad \& Empresa, 6(6), 9-41.

Aktouf, O. (2008). Gobernancia y pensamiento estratégico: Una crítica a Michael Porter. Administración y Organizaciones, 11(21), 157-183.

Aktouf, O., Chenoufi, M., \& Holford, W. D. (2005). The false expectations of Michael Porter's strategic management framework. Problems and Perspectives in Management, 4, 181-200.

Ardila, E. (2013). Prácticas ilegitimas en la gestión pública colombiana-Estudio del caso: grupo Nule. (Tesis de Maestría). Universidad Nacional de Colombia.

Bauman, Z. (2011). Collateral damage: Social inequalities in a global age. Polity Press.

Behrman, J. R., Gaviria, A., \& Székely, M. (2002). Social exclusion in Latin America: Introduction and overview. SSRN Electronic Journal. https://doi. org $/ 10.2139 /$ ssrn.1814705.

Bevir, M. (2008). Key concepts in governance. Sage.

Bortagaray, I., \& Gras, N. (2014). Science, technology, and innovation policies for inclusive development: Shifting trends in south America. In G. Crespi \& G. Dutrénit (Eds.), Science, technology and innovation policies for development (pp. 255-285). Springer.

Cepal. (2006). Defeating poverty through social inclusion. ECLAC. Santiago de Chile.

Colmenares, Rafael. (2013). ¿ Gobernanza del agua o justicia del agua? Available at http://viva.org.co/cajavirtual/svc0342/articulol2.html. 
Comisión Económica para América Latina y el Caribe-CEPAL. (2016). Desarrollo social inclusivo: una nueva generación de politicas para superar la pobreza y reducir la desigualdad en América Latina y el Caribe. Santiago de Chile.

De Ferranti, D., Perry, G. E., Ferreira, F., \& Walton, M. (2004). Inequality in Latin America: Breaking with history? The World Bank.

Dutrénit, G., \& Sutz, J. (Eds.). (2014). National innovation systems, social inclusion and development: The Latin American experience. Edward Elgar.

Economic Commission for Latin America and the Caribbean (ECLAC). (2019). Social panorama of Latin America (LC/PUB.2019/22-P/Rev.1). Santiago

ECLAC, CAF and OCDE. (2019). Latin American economic outlook 2019: Development in transition. OECD, CAF, ECLAC. Santiago de Chile.

Goda, T., Onaran, Ö., \& Stockhammer, E. (2017). Income inequality and wealth concentration in the recent crisis. Development and Change, 48(1), 3-27.

Gough, I. (1996). Social welfare and competitiveness. New Political Economy, I(2), 209-232.

Knorringa, P., Peša, I., Leliveld, A., \& Van Beers, C. (2016). Frugal innovation and development: Aides or adversaries? The European Journal of Development Research, 28(2), 143-153.

Krugman, P. (1994). Competitiveness: A dangerous obsession. Foreign Affairs, $73,28-44$.

Kuhlmann, S., \& Ordonez-Matamoros, G. (Eds.). (2017). Research handbook on innovation governance in emerging economies. Edward Elgar.

McCloskey. D (2019). Interview for a Colombian Newspaper, January 2019. Available at: https://www.deirdremccloskey.com/docs/pdf/McCloskey_Col ombiaInterviewJan2019.pdf.

OECD. (2017). Enhancing social inclusion in Latin America: Key issues and the role of social protection systems. OCDE.

Ordoñez-Matamoros, G., Centeno, J. P., \& Orozco, L. A. (2021). Las ciencias sociales y humanidades en la cuarta revolución industrial. Retos y oportunidades. Colección Así Habla el Externado. Tomo II Tecnologías Regulación y Políticas Públicas. Universidad Externado de Colombia.

Orozco, L. A., \& Chavarro, D. A. (2011). El programa de investigación del CIMPAT-Centro de investigaciones en microbiología y parasitología tropical de la Universidad de los Andes. Ediciones Uniandes.

Orozco, L. A., Chavarro-Bohórquez, D. A., Olaya, D. L., \& Villaveces, J. L. (2007). Methodology for measuring the socio-economic impacts of biotechnology: A case study of potatoes in Colombia. Research Evaluation, 16(2), $107-122$.

Orozco, L. A., Villaveces, J. L., Ordoñez-Matamoros, G., \& Moreno, G. (2019). Innovation policy and governance networks on national innovation systems. In G. Catalano, C. Daraio, M. Gregory, H. Moed \& G. 
Ruocco (Eds.), 17th International Conference on Scientometrics \& Informetrics, ISSI 2019-Proceedings (Vol 1, pp. 541-553). Sapienza University. Available at: http://www.issi-society.org/publications/issi-conference-procee dings/proceedings-of-issi-2019/.

Orozco, L. A, Beltrán, C, Vargas, C, García, L. F., \& Ruiz, M. (2018). El fraude en Interbolsa y Fondo Premium en el caso Fabricato. In J. C. Henao \& C. E. Ruiz-López (Eds.), Corrupción en Colombia. Tomo 3. Corrupción privada. Colección así habla el Externado. Universidad Externado de Colombia.

Sanabria, J., \& Orozco, L. A. (2021). Del capitalismo liberal a la economía colaborativa, nuevos modelos de negocio y retos para el marco institucional. Colección Así Habla el Externado. Tomo IV “Tecnologías Negocios y Gestión". Universidad Externado de Colombia.

Rhodes, R. A. W. (1996). The new governance: Governing without government. Political Studies, 44(4), 652-667.

RICyT. (2019). El estado de la ciencia. Principales Indicadores de Ciencia y Tecnología Iberoamericanos/Interamericanos. Buenos Aires.

UN. (2016). Identifying social inclusion and exclusion. United Nations. http:// www.un.org/esa/socdev/rwss/2016/chapterl.pdf.

Williamson, O. E. (1996). The mechanisms of governance. Oxford University Press.

Williamson, O. E. (2005). Transaction cost economics: The process of theory development. Great minds in management: The process of theory development (pp. 485-508).

Zurbriggen, C. (2011). Gobernanza: Una mirada desde América Latina. Perfiles Latinoamericanos, 19(38), 39-64. 